\title{
FUELLING DISDAIN: PRESIDENT TRUMP'S POLICY TOWARDS THE ISRAELI-PALESTINIAN CONFLICT
}

\section{Abdelkrim DEKHAKHENA}

\begin{abstract}
For decades, evangelicals have generally supported Republican candidates for being more religiously committed. This was reflected in the tremendous support Trump received in the 2016 election, which brought him to the White House. Trump's success has raised serious concerns about the state of U.S. policy as well as America's future role in the world. The study stems from concerns about U.S. foreign policy, accompanied by widespread controversy under President Donald Trump, particularly among those interested in the Palestinian issue, which was fuelled by the President's shocking remarks and speeches. Although Arab leaders have agreed with Trump's explicit statements of preparation to fight ISIS, the Israeli-Palestinian conflict remains a public criticism. While Trump represents a series of contradictions, his close ties with Israel and the 'deal of the century' resolution have made Middle Eastern politics more complicated and have made it more difficult to find a just solution to the crisis. This paper discusses Trump's new policy towards the Israeli-Palestinian conflict and his tendency to fuel contempt rather than compromise. The study attempts to analyse the position of the U.S. President Donald Trump in light of his special relationship with evangelicals and to understand its implications for future conflict prospects.
\end{abstract}

KEYWORDS: U.S. Foreign Policy, Donald Trump, Israeli-Palestinian conflict, Middle East, International Relations, Conflict Management.

\section{INTRODUCTION}

For decades, evangelicals have generally supported Republican candidates for being more religiously committed. This was evident in the tremendous support Trump received in the 2016 elections, which brought him to the White House. The outcome of the 2016 presidential and congressional elections marks a turning point for the United States and its international role -not just, because the White House will transfer from Democratic to Republican Party control, but also because the man elected to the presidency, Donald J. Trump, takes office with no prior experience in government and, in many respects, an apparently flexible outlook on domestic politics and foreign policy. Trump's campaign was marked by his frequent explicit rejections of his own party's positions and leaders. In fact, he

\footnotetext{
* Associate Professor of American Civilisation and Literature, Department of English Language and Letters, 8 Mai 1945 Guelma University, Algeria, dakc01969@gmail.com, ORCID: 0000-0003-0354-9130
} 
was elevated to the presidency precisely by his outsider status. Trump's foreign policy has been driven primarily by the pursuit of American economic advantage, at the expense of some of the security concerns of his allies.

For the past two decades, the process of negotiations and the peaceful political settlement of the Israeli-Palestinian conflict under American supervision -as the sole and official sponsor- have paved the way for the existence of a distinctive context for the analysis and interpretation of American political behaviour. However, the new developments in the conflict within the framework of President Donald Trump's single term and his recognition of Jerusalem as the capital of Israel intensified the controversial perceptions of the conflict, especially as he had given orders to start the process of moving the United States embassy from Tel Aviv to Jerusalem.

The Middle East was a key testing ground for Obama's foreign policy. The Arab Spring, NATO's multinational military intervention in Libya, the Syrian civil war, and the violent process leading to the Iranian nuclear deal can all be seen as formative passages of the Obama Doctrine. Overcoming the numerous crises, that still tragically plague the Middle East, has been a decisive challenge for the Trump administration as well (Nasr, 2016).

Despite Trump's absolute support from Arab leaders for his willingness to fight ISIL, the Israeli-Palestinian issue remains a matter of public criticism. If Trump were determined to fight terrorists and enjoyed Arab leaders' support, would he then turn his back to the American commitment to the Palestine issue? Although, Trump represents a series of contradictions that make Middle Eastern politics seem more complicated, his close relations with Israel can result in a distortion to the Israeli-Palestinian crisis. This paper deliberates on Trump's policy toward the Israeli-Palestinian conflict and his propensity to fuel disdain among the two competing parties.

U.S. foreign policy has adopted the Palestinian issue in a linear way in its political behaviour with some detailed or temporary interruptions, and according to the course of its national interests. The balance of power and change has been felt in the struggle and the developments of the international environment. The negotiation process and peaceful political resolution of the Israeli-Palestinian conflict over the past two decades, overseen by the United States as the only official sponsor, has laid the groundwork for an outstanding context for analysis and interpretation of American foreign policy action.

Through 2001, the administration of President George W. Bush, Jr. - in light of the final exit of Palestinian leader Yasser Arafat from the scene of the conflictcaused a sharp reversal in the dynamics of the conflict, and a visible change in American foreign policy toward the Palestinian issue as a direct major player. However, controversial opinions have emerged since the announcement of the preliminary results of Donald Trump's victory (2017) about the nature of his 
personality and the contents of his political speech, especially since the Republican candidate's positions on U.S. foreign policy in the Middle East have been contradictory and unclear (Ahmed, 2017). He expressed his orientation towards the primacy of realism in the promotion of these interests (Ahmed, 2017). What is striking about Trump's Middle East policy is his close relationship with Israel, and his outspoken and hostile attitude towards the rejection of the Palestinian-Israeli settlement (Ahmed, 2017).

American foreign policy governs the direction of the Palestinian issue into two main criteria that are not overlooked by any president: the strategic interests of the United States in the Middle East, and its strategic relationship with Israel (Ziada, 2017: 19). Accordingly, we will address the official American position on the issue of the Palestinian state starting with approaches of the Bushs, passing through the tenure of former U.S. President Barack Obama, until the time of the current President Donald Trump, with special emphasis on the Trumps 'Deal of the Century'. This research is analytical in nature. Thus, it will mainly rely on materials on U.S. foreign policy toward Arabs and Muslims and Israel and Palestine from scholarly works, expert opinions and other reliable sources to reach a credible conclusion.

\section{AMERICAN INTERESTS AND THE ISRAELI-PALESTINIAN CONFLICT}

U.S. strategic interests in the Middle East are based on basic interests. The most important of which is to strengthen its global standing and maintain leadership in the world. In order to maintain its primacy in global politics and economy, the U.S. efforts to maintain its military superiority by developing defensive and military systems that guarantee control and neutralise the military capabilities of other major powers. What really concerns the United States is to neutralise its rival powers in areas of international conflict, as it did when it laid red lines on some areas of international competition between it and the Soviet Union in the past. So is its policy in the Middle East.

The Middle East, especially the Arab Gulf states, is the main source of oil for the United States, as the world's most sought-after commodity, and is of great strategic importance in wartime. ${ }^{1}$ U.S. policy has built on these interests consistent and changing policies. It is creating strategic alliances in the region, mainly with Israel, that protect the interests of the United States and represents an advanced base in the region, and is keen to continue its alliance with Egypt through the provision of assistance and strengthening political relations. The United States and Israel enjoy one of the strongest political and military alliances in the world. U.S. political support for Israel is not only about Palestine but also about regional geopolitics.

In 2015, a U.S. national security advisor noted; 
It is definitely in our national security interest ... [to] facilitate the forging of a two state solution ... a secure and democratic, Jewish Israel and a secure and democratic Palestine, living side by side. (Karna Adam et al., 2015).

U.S. engagement in the Israeli-Palestinian conflict should not be taken for granted. Instead, the United States must consider whether and how it should involve itself. To do so, it is critical to define Washington's enduring foreign policy interests. These include the preservation of national security, economic prosperity, the spread of democratic values, and maintaining its world leadership. U.S. engagement in and resolution of the Israeli-Palestinian conflict could produce several tangible benefits to the United States.

The Middle East has long been of utmost importance to the United States as successive administrations pursue a series of interrelated goals, including securing vital energy resources, eliminating the influence of Soviet Union and Iran, ensuring the survival and security of Israel and its Arab allies, countering terrorism, promoting democracy and reducing refugee flows. As a result, the United States sought to resolve the Israeli-Palestinian conflict, which has been the main driving force behind the region, to achieve these strategic goals, while balancing its support for Israel and promote greater stability in the region.

Ever since the United States replaced the British Empire in the 1940s, it has sought to preserve its strategic interests and those of its allies in the Middle East. Considering it the heart of the world because of the oil wealth that the global economy depends on, especially the American economy; whoever controls it controls the world. Consequently, the United States is active in its endeavour to tighten control of the Middle East in close cooperation with opposing regional and international actors, some are even intensely hostile to one another, and Israel is one of the most important of these actors (Basevich, 2004). Successive U.S. administrations find it unnecessary to change those supports, as they did with Iran, as well as with Iraq.

In this regard, the United States did not differ much from the previous European empires that were searching for new regions that would meet their requirements on two levels. The first: obtaining the raw materials necessary for its industrial employment on the one hand, and the second: the rush towards population blocs in order to expand the creation of markets to discharge their commodity surplus on the other hand. At the time, there was nothing better than the Middle East, in which the interests of the major powers were available in their different directions. This is in view of the fact that whoever controls the Middle East controls global oil, and whoever controls the global oil controls the world's economy at least for the foreseeable future (Amin et al., 2004, p. 72).

Therefore, there was an eagerness to be present in the region and to contribute to the management of its issues, especially the Palestinian question (Perry, 1995, p. 8). Americans realise that securing the interests of the United States in the long run is linked to their active role in resolving issues and crises in 
the region. Those interests in the region are intrinsically related to developments on the Arab-Israeli stage. This requires decision makers in the United States to combine two extremes: supporting Israel, and maintaining their relations with the Arab peoples, especially the Palestinian people on good terms (Walt \& Mearsheimer, 2007, p. 96). American policy regarding the Palestinian issue is determined in light of the global strategy of the United States and its main interests in the Arab region. It considers that preserving its interests in the Middle East is one of the priorities of American foreign policy towards the region (Vatikiotis, 1971, pp. 120-122).

The experience of American interaction with the countries and peoples of the region reveals the reality of the correlation between the Palestinian issue and the guarantee of preserving American interests in the region. Therefore, the United States has always had to pay attention to the Arab-Israeli conflict and its developments on both sides. During successive administrations, U.S. policy towards the Israeli-Palestinian conflict has not experienced any dramatic change. Under the guise of reconciliation, U.S. presidents have worked closely with Israel to ensure its political, economic, and security interests. The United States' continued provision of financial and military support to Israel is a clear sign of this trend. On the other hand, U.S. administrations have treated the Palestine issue as a refugee issue rather than a national issue with historical roots in their land and existential concerns. The existence of the Palestinians was only ostentatiously recognised by the United States, as evidenced by the United States' refusal to recognise the PLO after its creation. The U.S. administrations have also turned a blind eye to Israel's systematic denial of basic Palestinian rights and have struggled to legitimise the Israeli actions as a fight against terrorism. The conflict has always been a priority for the American administrations often times to the detriment of their political orientations (Quandt, 1981, pp.138-139).

The U.S. has aspired to be the Middle East's dominant power since the Second World War. For decades, successive administrations have considered military supremacy in the region to be indispensable to maintaining influence over flows of its hydrocarbons to international markets -a task each has deemed essential to the U.S.'s global standing. ${ }^{2}$ Washington's interest in oil from the Arabian/ Persian Gulf has never been primarily about satisfying the U.S.'s own energy needs (a point overlooked by claims that the 'shale revolution' allows Washington disengage from the region); it is about controlling who gets access to this oil, thereby bolstering U.S. influence in other vital regions. ${ }^{3}$ U.S. officials have long seen alliances with Saudi Arabia, Iran (until the 1979 revolution), Israel (after the 1967 Arab-Israeli War) and Egypt (since the 1978 Camp David accords) as key to realising this agenda.

The Cold War significantly constrained the U.S. quest for regional dominance. When it ended, Washington judged itself freer to forge a highly militarised, proU.S. political and security order in the Middle East -and to ostracise and undermine those countries unwilling to subordinate their strategic independence 
to it. ${ }^{4}$ At that time, U.S. policy was to pursue an irresponsible vision of regional or global hegemony especially in the Middle East. In this context, Trump wanted to "make America great again" by reconstructing its economy and projecting its military capability (Curran, 2018).

Conventional political literature, especially when dealing with the nature and content of the political objectives of the United States of America in the Middle East region, has set two main objectives. The first one is the position of the United States of America on the Arab-Israeli conflict, which supports Israeli policies, especially on the issue of Palestinian refugees, and the Occupied Arab Territories inside or outside Palestine, whether in 1948 or in 1967. The second goal is to support some friendly regimes that are loyal to U.S. policy in the Arab region mainly Israel. The United States remains the main actor in the Palestinian-Israeli conflict, and despite the role played by several countries in influencing the course of events. Washington is the most influential player in the management of the conflict, giving great importance to the details of the new U.S. peace initiative or the so-called 'deal of the century'.

\section{U.S. POLICY TOWARD THE ISRAELI-PALESTINIAN CONFLICT 1991-2016}

The George H. W. Bush, Bill Clinton and George W. Bush administrations differed on elements of Middle East policy -such as the role of diplomacy between Arabs and Israelis, and the balance between democracy promotion and backing pro-US authoritarians- but all pursued primacy grounded in a US-led regional order. At the beginning of the Gulf War in 1991, President George H.W. Bush declared solving the Arab-Israeli conflict among his post-war goals. On 6 March 1991, he outlined a framework for peace based on U.N. Security Council Resolutions 242 and 338 and the principle of 'land for peace'. Secretary of State James Baker organised a peace conference in Madrid in October 1991 that launched almost a decade of the 'Oslo process' to achieve peace.

When the 1990 s begun, President William Clinton, who had no foreign policy experience, succeeded in bringing the Palestinian and Israeli sides together as part of its attempt to reinvigorate the peace process after years of stagnation. He asserted that only the region's leaders can make peace and vowed to be their partner. With the Hebron Protocol of 1997, however, the United States seemed to become an indispensable and expected party to Israeli-Palestinian talks. Clinton mediated the 1998 Wye River Memorandum and the United States undertook to coordinate its implementation. He personally led negotiations at Camp David in 2000. President Clinton, Israeli Prime Minister Ehud Barak, and Palestinian Authority (PA) Chairman Arafat held a summit at Camp David, from 11 to 24 July 2000 , to forge a framework accord on final status issues. They did not succeed, however. The parties had agreed that there would be no agreement unless all issues were resolved. Jerusalem was the major obstacle. 
The fleeting momentum initiated by the Oslo Accords had come to an end. The Palestinians understood that the so-called peace agreement does nothing to end their grievances. The on-going occupation has denied them basic rights such as autonomy, free access to Jerusalem, the right of return of refugees, property and security. Extremely upset by the violation of their fundamental rights, as well as their failure to make the economic progress promised in the Oslo accords, Palestinians declared the Second Intifada which broke out soon after the collapse of negotiations between then Israeli Prime Minister Ehud Barak and then President of Palestine Yasser Arafat.

On 6 February 2001, Sharon was elected Prime Minister and vowed to retain united Jerusalem (as Israel's capital), the Jordan Valley, and other areas for security. Sharon's associates asserted that the results of negotiations at and after Camp David were "null and void". The Bush Administration said that Clinton's proposals "were no longer United States proposals" (Migdalovitz, 2006, p. 3). Sharon sought an interim agreement, not dealing with Jerusalem, Palestinian refugees, or a Palestinian state and, on 13 April, said that he could accept a disarmed Palestinian state on $42 \%$ of the West Bank (Migdalovitz, 2010).

The George W. Bush Administration initially sought a less prominent role, and Secretary of State Colin Powell did not appoint a special Middle East envoy. The post 9/11 war on terrorism prompted renewed U.S. focus on a peace process, emphasising as its goal a democratic Palestinian state as a prerequisite for achieving peace. Indeed, on 30 April 2003, the United States, the U.N., European Union, and Russia (known as the "Quartet") presented a "Roadmap" to Palestinian statehood within three years. However, neither Israel nor the Palestinians have implemented it for lack of compromise. As for the Israelis and Palestinians, none of them wanted to say no to President Bush, who flared up after Saddam's defeat. Prime Minister Sharon, knowing that most Israelis believe the United States has eliminated a strategic threat to Israel, will not refuse an initiative of the victorious president. Likewise, neither Arafat nor the reformist Palestinian leadership is interested in rejecting an American initiative under these circumstances. In contrast, the Palestinians demanded the intervention of the world's sole superpower to transform the situation on the ground.

Secretary of State Condoleezza Rice also did not name a special envoy, asserting, "Not every effort has to be an American effort. It is extremely important that the parties themselves are taking responsibility" (Gearan, 2005). She encouraged Israelis and Palestinians to act, but personally mediated a November 2005 accord to reopen the border crossing between Gaza and Egypt after Israel's withdrawal from Gaza. In 2007, she engaged again partly in order to elicit the support of moderate Sunni Arab governments to thwart the rise of Iranian influence. Those governments see resolution of the Palestinian issue as a key to regional stability and to denying Iran opportunities for destabilising actions. 
The Joint Understanding presented at the November 2007 Annapolis Conference created a new role for the United States as "judge" of the parties' fulfilment of their commitments under the 2003 international Road Map to a twostate solution. In January 2008, President Bush appointed (Air Force) Lt. Gen. William Fraser III, assistant to the Chairman of the Joint Chiefs of Staff, to monitor compliance with commitments. Gen. Fraser, who has been replaced by Lt. Gen. Paul J. Selva, was not to mediate or enforce compliance, but bring the attention of the parties to their actions and encourage them to move forward on their obligations (Hadley, 2008). Fraser was to visit the region "from time to time," but the trilateral mechanism barely functioned.

Barack Obama emerged as a presidential contender partly by challenging aspects of this agenda. In the 2008 Democratic primaries, he distinguished himself from his main rival, Hillary Clinton, by opposing the 2003 Iraq invasion (which she had endorsed) and advocating diplomacy with Iran (which she opposed). As president, he sought to 'rebalance' U.S. strategy by shifting high-level attention and resources from the Middle East to Asia.

The Obama Administration began 2010 with a renewed effort to restart negotiations. Media reports suggested that it was preparing "letters of guarantee" that would assure the Palestinians that the 1967 borders would form the basis of the negotiations and the Israelis that post-1967 demographic changes (some settlements) would be taken into account (Lee, 2010). The so-called "Arab Spring" changed the American policy in support of Israel, as it tried in every way to separate it from its potential positive repercussions on the Palestinian situation (“The American Position”, 2012).

The American policy regarding the Palestinian-Israeli conflict continued to follow the same frameworks and strategies that were used in the past, to prove that the American policy towards the Palestinian-Israeli conflict enjoys a state of stability and not differs from one president to another, whether Republican or Democratic, and that what govern this policy is primarily American interests.

The Obama administration has made it a top priority to relaunch the stalled peace process in the region with the aim of achieving a two-state solution. Obama appointed to this end Congressman George Mitchell, who made an effort to launch negotiations and announced a project to this end, which included launching bilateral negotiations under the auspices of America and initiating Arab normalisation steps (“The American Position", 2012). But President Obama not only reneged on his promises, but also publicly declared his full support for Israel. Before the end of 2009, the American administration retreated from what it had previously announced, declaring its acceptance of the project presented by Israeli Prime Minister Benjamin Netanyahu, which includes a partial freeze of settlement growth and the launching of negotiations without any conditions (Muhammad Hussein, 2017). The American retreat came because of the inability of Obama and 
his supporters to put pressure on Netanyahu, who is strongly supported by the Zionist lobby in the United States (Migdalovitz, 2010, pp. 2-3).

The United States' 2015 nuclear agreement with Iran has weakened the stability of its alliance with Israel, threatening to undermine the transparency of future peace-making efforts. Israel explicitly opposed the agreement, calling it too lenient. Spearheaded by President Obama, the agreement lifted international economic sanctions against Iran in exchange for restrictions on its nuclear program. Alongside a bloc of Congressional Republicans, Prime Minister Netanyahu emphatically opposed the agreement, contending that Israel's security is paramount (Greenberg, 2015). Despite a high-stakes congressional lobbying campaign by Netanyahu and AIPAC in an attempt to derail the agreement, Congress ultimately did not strike down the agreement. It was evident that Obama adopted a comprehensive approach to the crises of the Middle East by looking at the region as a whole and not fully realising the nature and specificity of the Palestinian-Israeli conflict (Muhammad Hussein, 2017).

The United States has given greater importance to other issues and regions. This has made interest in the settlement of the Israeli-Palestinian conflict in particular on the side-lines of the American agenda. This has enticed other States to try to intervene on the conflict line, to replace the United States of America, or at least to participate in negotiations on this issue. This gave the impression that the U.S. role in the Israeli-Palestinian conflict and other crises related to the Middle East had declined. Not only that, but it has also had a negative impact on U.S. interests and relations in the region, especially with the Gulf Arab states. The latter's relations with the United States have been strained during the last period of Obama's term because of his loyalties and rapprochement with Iran without regard to the major interests that bring the two countries together -the imbalance that President Donald Trump is now trying to address by restoring relations with the Gulf states and the region, and even developing them in a way that preserves America's major interests in the region.

\section{U.S. POSITION ON THE PALESTINIAN ISSUE UNDER PRESIDENT DONALD TRUMP}

During his election campaign, Trump regularly spoke of a foreign policy that focuses on American interests. This contradicts preceding U.S. Presidents who spoke of projecting American values through their foreign policies both Obama and George W. Bush used their inaugurals to reaffirm the goal of promoting democracy and human rights. President Trump revealed his realist penchant in his approach not only to American policy, but undeniably towards his views on foreign policy, as both approaches must go hand-in-hand in his realist paradigm.

As a candidate, Trump fiercely criticised America's policy in the Middle East. Trump repeatedly expressed contempt for longstanding Arab partners of the U.S. such as Saudi Arabia and other Gulf countries, on the ground that Washington gives them protection without getting enough in return (Trump, 2016, April 27). 
During the campaign, however, Trump showed a radically different attitude toward Israel. The new president described Israel as "our great friend and the one true Democracy in the Middle East", and frequently declared -with perhaps debatable accuracy - that his predecessors were not supportive enough (Trump, 2016, April 27). What Trump's rhetoric appears to suggest, at any rate, is that the new president appreciates Israel's military prowess as a valuable asset for America's security policy.

Trump may turn out to be a pragmatist. After all, he proudly sees himself as a great "deal-maker". According to Max Boot (2016), beyond the blatant differences in terms of style and rhetoric, Trump's foreign policy may in fact show a substantial degree of continuity with the foreign policy approach of the Obama administration. In fact, during a major campaign speech, Trump himself argued that he seeks "peace through strength" and that "In a Trump Administration, [his] actions in the Middle East will be tempered by realism" (Pagliarulo, 2017). This can be a frightening perspective according to Boot.

Trump never spelt out his foreign policy agenda. In the pre-election phase, his ramblings on the topic ranged from isolationism and trade protectionism to the possibility of an all-out war with China, the Muslim and Arab world, North Korea and Iranian nuclear deals. Since the U.S. is already the most powerful player in the system, it will have to continue to exhibit the kinds of foreign policies that allow it to maintain the status quo and its pre-eminent position in global affairs. That is, application of a mix of both soft and hard power that displays in smart power policy will stay more or less the same (Pijovic, 2016).

Trump became a new phenomenon and a serious security concern against international relations between the Arab/Muslim countries and the United States of America ("Trump's Executive Order, 2017). Indeed, the emergence of Donald Trump as a U.S. President has critically put under question the future of peace negotiations between the two parties. To no surprise, Trump's policy on the Arab-Israeli conflict, in his electoral campaign, raised fears among Palestinians that as president he would carry out his threats to ratchet up support for Israel: not only crushing hopes of a two-state solution but also potentially worsening an already fragile domestic Palestinian situation. Trump would simply turn a blind eye to Israeli offensive practices, particularly expanding settlements and fulfil his election promise to move the U.S. Embassy from Tel Aviv to Jerusalem, which would trigger a new cycle of violence and instability (Jaraba, 2016).

The Israel Prime Minister is the first leader to visit Donald Trump after his swearing. In their press conference, Trump said that the two-state solution used to be the easier route to peace between Israelis and Palestinians and that it is up to Israelis and Palestinians to decide whether they want to live in peace in two states or one (Lustick, 2017). Upon his 50 days in office, Donald Trump has extended an invitation to the Palestinian Authority, President Mahmoud Abbas to visit the White House. The invitation came during the first conversation between 
the two leaders since Trump entered the office. As a reaction, Al Jazeera notes that while Trump's talk of a ban on Muslims into the U.S. has undoubtedly angered Muslims, could his promise of neutrality on Israeli-Arab relations be enough to offset this ban? However, to Arab-Muslim Americans who have never experienced the U.S. that seemed fair or balanced in its dealings with Israel, it would help to ameliorate some of that anger ("What Would Donald Trump Mean For The Middle East?, 2016).

Israeli-US relations under the eight years of the Obama administration were regarded as cold and even arctic due to lack of tangible solution to Israel-Palestine crisis (Lustick, 2017). Although many in the Arab world were suspicious of U.S. intentions even before the breakdown of the peace process, their opposition to U.S. policy was muted in part by their belief that the peace process was working and that the United States remained indispensable to its success.

Just as America's interest in the flow of Gulf oil will endure for the foreseeable future, so too will America's interest in a secure and peaceful Israel. Israel's long-term security requires a stable peace with its neighbours. Given continued American military and technological support, conventional Israeli security is more easily assured today. The greater current threat to Israel comes from regional instability that breeds terrorism and low-level conflict, and from unconventional capabilities that can best be controlled through negotiated incentives in an environment of peace. Clearly, the broader the peace coalition, the easier it will be to confront those who remain outside of it (Siegman, 2017).

The United States has played a prominent role as a mediator and facilitator for the rounds of negotiations and agreements that have gone through the ArabIsraeli conflict, starting with the completion of the Egyptian-Israeli peace agreement. The administration is trying to address multiple previous failures in this file, adopting a new pattern that departs from traditional patterns of negotiations, and relies on a specific vision that can be set in advance. A policy that is different from the policy of negotiations in which the two parties were hosting the conflict without agreeing on specific terms of discussion.

Since Israel's declaration of the occupied Palestinian territories in 1948, it has enjoyed significant Western material, military and moral support, particularly exceptional American sponsorship, where the United States of America has provided political, diplomatic, economic and military support to Israel at the level of bilateral relations, and at the level of the U.S. position and role in the United Nations. The United States of America vetoed any attempt to condemn Israel, or any attempt to obtain any resolution obliging Israel to implement resolutions of international legitimacy, related to the Arab-Israeli conflict or legal agreements or references related to the Palestinian-Israeli conflict and the Palestinian-Israeli peace process. 
The positions and various policies of the U.S. administrations and their policies on the Palestinian-Israeli conflict and the peace process were largely in line with Israeli perceptions and visions. The United States of America has excluded any state, international organisation and others from any role it can play in final resolution issues. The United States administration continued its bias in the 1991 Palestinian-Israeli peace process talks at the Madrid Peace Conference, and the subsequent direct secret negotiations between Palestinians and Israelis. This eventually led to the signing of the Oslo Agreement (in September 1993), which in essence did not reflect the aspirations, sacrifices and hopes of achieving the Palestinians legitimate rights and independence. All this happened under the American sponsorship that provided Israel with all the provisions of authoritarianism and violation of international obligations and legal references.

Successive U.S. administrations have continued their unwavering support for Israel on the same approach and content, until President Donald Trump and his administration have embraced the entire right-wing Israeli agenda. Since his candidacy in the March 2016, Trump has pledged to move the U.S. embassy from Tel Aviv to occupied Jerusalem, to recognise the occupied city of Jerusalem as Israel's capital, and expressed his explicit and subsequent abandonment of the two-state solution option. Three of his predecessors, the European Union and the United Nations have adopted the idea as the only way to end the PalestinianIsraeli conflict and achieve the Palestinian-Israeli peace process.

Ulson Gunnar explains that the historic U.S. foreign policy inclination can be traced back decades, "While the US has all but declared its intent to establish global hegemony for decades, it uses the pretext of seeking global peace, security and stability as cover along the way" (Gunnar, 2017). He carries on by stating that the U.S. used its proxy state of Israel to destabilise the Middle Eastern region by inciting wars between them and Arab nations, all with the goal of maintaining its global hegemony (Gunnar, 2017).

\section{TRUMP'S ROLE IN THE ARAB-ISRAELI CONFLICT}

The Trump election program outlined support of the two-state solution as a general idea, as he believes that the American role should be limited in negotiations between the Israeli and Palestinian sides to the role of the 'facilitator of negotiations'. He criticised in this context the weakness and inefficiency of the United Nations, rejecting the idea of imposing a solution to the Palestinian issue through the United Nations (Jaraba \& Bin Sheetrit, 2016). He then reaffirmed that the two-state solution is not the only way to end the conflict, and that he is open to alternative options if they lead to peace, suggesting that the solution must be through the parties' negotiations, and that he will use the veto against any solution adopted by the Security Council.

President Trump believed that he would bring peace between Palestinians and Israelis during his administration, after his predecessors in previous 
Administrations failed to achieve it. However, he backtracked on his previous positions by saying that "his administration is not committed to a two-state solution as the basis for resolving the Palestinian-Israeli conflict" (Ziadeh, 2017, p. 369), arguing that a two-state solution is not the only way to achieve a peace process. After his first speech about the Palestinians' rights, and to remain neutral during his election campaign, he completely turned around pledging to move the U.S. Embassy from Tel Aviv to the occupied city of Jerusalem, and absolute support for Israel.

According to that vision, Trump ignored the Palestinian-Israeli conflict and the peace process in his first presidential address (Ziadeh, 2017, p. 369), giving the initial impression that he had decided to give Israel what it wanted to achieve. He clarified that the peace process must be conducted between Palestinians and Israelis without any dictates or pressure from others, primarily in line with Israeli interests. The Trump administration has always maintained that it is not prepared to pressure Israel to comply with the peace references or the resolutions of international legitimacy. On the contrary, it is exerting political, economic and financial pressure on the occupied Palestinian side of its territory to make further concessions in Israel's interest.

Trump's attitudes and vision toward the Palestinian-Israeli conflict have put the radical and distinct transformation of U.S. policy adopted by previous U.S. administrations. Even, international legitimacy and authority resolutions, particularly on the issues of the final solution of the future of the occupied city of Jerusalem, the issue of Palestinian refugees, the issue of borders, security and water, Israeli settlements and the two-state solution, in line with the Israeli extreme right and its policies and objectives.

President Trump may believe, truly and without doubt, that he is offering the "deal of the century". It is a great deal for Netanyahu and his government. Their positions on the Palestinians, more than ever, are America's positions. Through all the years of mediation in peace talks between Israel and the Palestinians, the top U.S. priorities have always been Israel's wishes, constraints and most of all its security. However, successive U.S. presidents accepted that peace required a viable Palestinian state alongside Israel, even if they were not prepared to allow it equal sovereignty (Bowen, 2020).

Nevertheless, Trump's tendencies to pursue Israeli vision and extreme-right goals have varied, from abandoning the two-state solution process to moving the U.S. embassy from Tel Aviv to occupied Jerusalem, recognising it as Israel's unified capital, turning a blind eye to Israeli settlements, settling the Palestinian refugee issue, and appointing many pro-Israel hardliners in his administration. His administration has considered Israel and its interests as the foundation and centrepiece of U.S. policy in the Middle East, and the bias and coverage of its occupation and crimes, its support and the rejection of sanctions, the general nature of this policy. 
Accordingly, Trump sought to impose Arab-Israeli normalisation as a condition for resolving the Palestinian-Israeli conflict by building a network of regional alliances that include a group of balanced Arab countries such as Saudi Arabia and Egypt alongside Israel, the new alliance responding to Israeli regional interests, particularly reducing Iranian influence in the Middle East, specifically in Syria. The coalition also aims to deal with threats from organisations and movements that embrace resistance, such as The Islamic Resistance Movement (Hamas), The Islamic Jihad in Palestine and Hezbollah in Lebanon. There are numerous leaks in this regard that specifically point to the role of Saudi Crown Prince Mohammed bin Salman in putting intense pressure on Palestinian President Mahmoud Abbas to respond to U.S. proposals with threats to cut off financial aid to the Authority in the event of a failure to respond (Al-Jazeera, 2017).

The most controversial Trump's policy toward Israel and Palestine is the relocation of the U.S. Embassy from Tel Aviv to occupied Jerusalem. However, Trump is not the first president to suggest moving U.S. Embassy in Israel to its original place, previous presidents like Clinton, H.W. Bush, George W. Bush and Obama often pledging to do this in their campaign speeches and political debates. Most probable these election pledges were only made to secure Jewish votes from the American public or perhaps the previous presidents lost their courage because of the international disapproval of moving the American Embassy to Jerusalem (Rinehart, 2018, pp. 25-45).

While Trump's foreign policy on Israel-Palestine remained vague during his campaign, high-profile individuals were trying to make a final mark on future initiatives. One of these people was the pro-Likud billionaire Sheldon Adelson, who supported Trump in May 2016 (Wermenbol, 2019). He funnelled tens of millions into Trump and other Republican campaigns' and has maintained direct line to the president (Elgindy, 2019). However, Adelson's support toward Trump expects something in return. Adelson thus demanded that Trump commits to moving the U.S. embassy from Tel Aviv to Jerusalem (Elgindy, 2019). Not only that, once Trump was in office, his administration adopted a more negligent attitude towards Israeli settlement than its predecessors did. Instead of urging Israeli to hold the agreement, the Whitehouse also alleged, "we don't believe existence of the settlement is an impediment to peace" (Elgindy, 2019).

Furthermore, officially recognising Jerusalem as the capital of Israel, President Trump changed nearly 70 years of U.S. foreign policy and made the U.S. on the opposite standpoint. While Trump wanted to overlook the legacy of the preceding leaders and make changes, he signed declarations loaded with warnings and exclusions that make his policy unclear (Tllovska-Kechedji, 2018, pp.120-130). Anderson explained that recognising Jerusalem as Israel's capital and announcing the relocation of U.S. embassy, do not reflect a departure from the strong commitment of the United States to facilitating a lasting peace agreement. The United States continues to take no position on any final status issues. The 
specific boundaries of Israeli sovereignty in Jerusalem are subject to final status negotiations between the parties (Anderson, 2017).

The United States is not taking a position on boundaries or borders because in this situation, Trump should assign either Palestine or Israel who will have ultimate sovereignty over Jerusalem. He recognised that Israel's sovereignty over some part of Jerusalem is enough for Jerusalem to be Israel's capital but did not specify which part. In that sense, Trump seems intentionally refusing to determine the rules or boundary points to West Jerusalem. Thus, this raises questions about his intentions, and many possibilities could happen due to his vague declaration (Anderson, 2017). That is going to lead to even bigger problems down the road.

President Trump believes that Israel is the primary ally of the United States of America in the Middle East. It is necessary to ensure their interests and strengthen their national security. So, Trump indicated in his speech to the AIPAC conference, his opposition to a political settlement between Israel and the Palestinians because it drops Israel's legitimacy and rewards Palestinian terrorism rather than confronts it (Suleiman, 2016, p. 5). This justifies his interest in economic peace based on money, support and bribery instead of political peace, ignoring and denying the rights and sacrifices of the Palestinian people, and the relevant international legitimacy and reference decisions.

\section{THE “DEAL OF THE CENTURY”}

Upon his entry into the White House, President Donald Trump vowed to put an end to the decade-long Israeli-Palestinian conflict by building a peace team made up of personal confidantes. Trump has, repeatedly called peace between Israel and the Palestinians the "ultimate deal". However, Trump's uncertainty and ambiguous foreign policy has created a dead pool towards many parties. Nevertheless, it is undeniable that Trump is the only U.S. Presidents after 70 years that has taken bold actions towards this conflict. Thus, many have questioned Trump's credibility due to certain approaches that he has taken in order to make his Peace policy succeeds. Trump has prioritised the conflict, holding several meetings with Arab leaders while preparing the deal to hear their point of view, especially as direct Israeli-Palestinian negotiations have stalled since 2014, and amid Arab consensus on the Arab peace initiative approved at the 2002 Beirut summit.

The "Deal of the Century" was prepared away from the usual U.S. political decision-making circles: three people, most notably his son-in-law and adviser Jared Kushner, along with U.S. Ambassador to Israel David Friedman and U.S. Envoy to the Middle East Jason Greenbllat, ${ }^{5}$ contributed to the secrecy of the final drafting. Trump and his administration recognise that the deal is not easy to implement, especially since the biggest concessions are on the Palestinian side. President Trump says his long-awaited Mideast peace plan is a road map for a 
"realistic two-state solution" that envisions Jerusalem as Israel's "undivided capital".

Moreover, Trump's remarks during the preparatory elections for the party nominations, in which he indicated that he would take a 'neutral' position in the Palestinian-Israeli conflict, raised a lot of controversy ("The Expected Policy of the Trump Administration", 2017). This position has been interpreted as requiring that negotiations between the Palestinian and Israeli sides be the basis for determining the form of a settlement. That is, it does not want a specific roundabout for the United Nations or the international community in this particular aspect, and this means that the issues of Jerusalem, refugees and borders are left to negotiate between the Palestinian Authority and Israel -the balance of bilateral forces ("The Expected Policy of the Trump Administration", 2017). This means providing the appropriate environment for the Israeli side to exert all available pressures on the Palestinian side to obtain the largest amount of gains.

However, the plan limits the sovereignty of a future Palestinian state. Israel would be in charge of maintaining security over the state of Palestine, which would be "fully demilitarised." The proposal also allows Israel to declare sovereignty over certain areas of the occupied West Bank, including Israeli settlements and the Jordan Valley. Trump heralded the plan as a "historic breakthrough," even though the Palestinian leadership, which severed relations with the U.S. administration as it took a series of pro-Israel moves, rejected it before the proposal was formally released.

\section{THE TRUMP'S ECONOMIC PLAN}

The White House has unveiled a $\$ 50$ billion Palestinian investment and infrastructure proposal aimed at supporting its much-anticipated "deal of the century" Middle East peace plan. ${ }^{6}$ The scheme, which calls for a mix of public and private financing and intends to create at least a million new jobs for Palestinians, was posted to the White House website before a two-day conference in Bahrain. The so-called "Peace to Prosperity" workshop in Manama on Tuesday and Wednesday (25-26 June 2019) is being held amid heavy scepticism about its viability, and outright opposition from Palestinian leaders. Speaking to Reuters, Jared Kushner said:

I laugh when [Palestinian leaders] attack this as the 'deal of the century'. This is going to be the opportunity of the century if they have the courage to pursue it.

In dealing with the Arab-Israeli conflict, the President seems to be dealing with economic logic, stalking gains that may appear new, believing that they may lead the parties to overlook fundamental differences that could cause problems and crises. This is where the economic component comes in. The Trump administration has pledged to drum up \$28 billion over 10 years to support Palestine, with $\$ 22$ billion of additional funding going to Jordan, Egypt, and 
Lebanon. This aid comes in the form of investment. The money would go toward infrastructure and transportation links, raising standards of living, and enabling broader regional trade. Funding would also be devoted to improving education, healthcare, and workforce development. Only small amounts of money were pledged at the Bahrain conference. But the U.S. has pledged that they're not going to let the process die for lack of cash (Bremmer, 2020).

The Trump administration, is seeking to economic(ise) the peace process, as temptations in exchange for concessions on the parameters adopted by the Palestinian negotiators. Donald Trump, during his meeting with Mahmoud Abbas at the White House (on 3 May 2017), indicated his aspiration to support the Palestinian economy. Trump aims to support and improve the economic situation in the territories of the Palestinian Authority (Ziadeh, 2017, p. 373) to encourage the Palestinian Authority to return to negotiations without conditions and without halting settlement activity; Thereby making economic peace an alternative to political peace based on a two-state solution. By providing job opportunities for the Palestinians in exchange for giving up their dream of liberation and establishing their state, without a capital in occupied Jerusalem or the return of Palestinian refugees, or the removal of illegal Israeli settlements in the West Bank and East Jerusalem.

The Bahrain conference, known as the "Peace Workshop for Prosperity with the aim of encouraging investment in the Palestinian territories", came in line with the American vision of President Trump and his administration. The Trump administration seeks to collect and display donations and investments from participating countries such as Saudi Arabia and the Gulf states, which may reach \$50 billion, in order to encourage the Palestinian Authority and the Palestinian people to accept the vision and policies of President Trump and his administration. This political money represents only a political bribery aimed at delegitimising the rights of the Palestinians and liquidating their cause.

At the conclusion of the Bahrain conference, Kushner accused the Palestinian leadership of failing to help its people, stressing that the door is still open for them to participate in the Washington peace plan, which was launched from the economic side of it in this conference. Kushner said that the door is still open for the Palestinians to join the American peace plan, whose political features have not yet been clarified, saying:

If they really wanted to improve the lives of their people, we have put in place a great framework that they can engage in and try to achieve ("The Bahrain Conference", 2019).

Based on these data, the Trump administration carries only economic proposals aimed at improving the economic situation in the Palestinian territories, and improving the daily life of the Palestinians, and not helping them to obtain their legitimate rights. This plan is considered compatible with the Israeli 
occupation. They have also suggested they are open to unilateral Israeli annexation of disputed territory. Officials say there is no intention of discussing the most contentious parts of their proposal to end the long-running conflict. Thus the core political issues that are key to resolving the dispute, such as borders, the status of the holy city of Jerusalem, Israel's security and the fate of Palestinian refugees, will not be raised.

While the White House called the plan "the most ambitious international effort for the Palestinian people to date", Trump's vague declarations create dead pool and confusing among Palestinians, Arab states and International Community regarding this conflict. Its economic proposal, however, makes no mention of a Palestinian state or an end to Israeli occupation. Trump also threatened to cut off financial aid to all who will vote for the draft United Nations resolution for the U.S. to withdraw its decision to recognise Jerusalem as Israel's capital. Many parties believe that, U.S. foreign policy on the Israeli-Palestinian conflict is confusing and not helping to resolve the problem. Notably absent, the Palestinians, whose input was not sought for the proposal. There are so many reasons why Netanyahu is happy with the plan, and so many why the Palestinians disagree.

\section{FUELLING DISDAIN}

Palestinians were outraged by the proposal. Opposition even appeared to unite long-time Palestinian political rivals the Palestinian Authority and Hamas, which governs the Gaza Strip. Palestinian President Mahmoud Abbas chaired an emergency meeting with Hamas, and called it a "new phase of Palestinian dialogue and joint work," according to local media ("President Receives a Call from Hamas Leader", 2020). Trump has described the plan as the "deal of the century," but Abbas called it the "smack of the century," saying it was an unacceptable attempt to "liquidate the Palestinian issue". Hamas leader Ismael Haniyeh said in a statement that "the new plot against Palestine is doomed to failure and Palestine will vanquish the colonisers at the end" ("Trump Says His Mideast Peace Plan", 2020).

Throughout, Israel argues the Palestinians turned down a series of good offers. The Palestinian negotiators say they made huge concessions, not least accepting Israel's existence in around $78 \%$ of their historic homeland. Palestinians in the occupied territories have protested against the US-led Middle East peace plan. The violence started when the embassy was moved as U.S. provokingly chose to launch the new embassy in Jerusalem on 14 May, the seventieth anniversary of Israel's independence. The worst is U.S. officials including Jared Kushner and Ivanka Trump rejoicing it in Jerusalem while many Palestinians were being killed less than sixty miles away (Elgindy, 2019).

Therefore, the recognition by the Trump administration during the Trump era of occupied Jerusalem as the unified capital of Israel (on 6 December 2017), and the transfer of the American embassy from Tel Aviv to it, demonstrated the 
truth of the American mediation and its siding with Israel. President Trump has aroused his recognition that occupied Jerusalem is the unified capital of Israel, disgruntled Arab and global reactions. Immediately, several Arab and Islamic governments condemned the American move, and considered this step as eliminating the peace process between the Palestinians and Israelis, and that it represents a threat to the stability and security of the entire region.

For his part, President Mahmoud Abbas considered that Trump's decision reflects the withdrawal of the United States of America from its role in mediating the peace process, and that the decision will not change the city's identity and history, and will remain the eternal capital of Palestine. While Ismail Haniyeh, head of the political bureau of the Islamic Resistance Movement (Hamas), called for the Palestinian mobilisation and the uprising in the face of the American decision ("What after Trump declared Jerusalem", 2017), a position, which in its content approached the positions of the Palestinian armed factions that called for a strike in the West Bank, Gaza Strip and occupied Jerusalem. While internationally, the European Union informed Israel of its rejection of Trump's decision, while Russian President Vladimir Putin criticised the U.S. administration's decision, describing it as increasing the complexity in the region and hindering the Palestinian-Israeli peace process ("What after Trump declared Jerusalem”, 2017, p. 2).

The decision to recognise occupied Jerusalem as the united capital of Israel overthrows seventy years of American foreign policy and international consensus which considers the fate of occupied Jerusalem as one of the most important issues of the final solution. It is the basis for any peace process, because it is considered the most complicated issue of the Palestinian-Israeli conflict and an important religious and political symbol for billions of people around the world.

Nevertheless, in one stroke, the annexation of the West Bank would create a political arena of immense potential. It would not generate many warm and fuzzy feelings, but it would transform politics from a zero-sum struggle between Israeli Jews and Palestinians to a more complicated and potentially more productive competition among different Palestinian and Jewish groups searching, within and across the boundaries of their national communities, for political allies and power.

Naftali Bennett, the Israeli Minister of Education, acknowledged that Trump's prior and supportive stances of Israel would destroy the idea of a Palestinian state (Al-Sahli, 2017, p. 58), and that his position is not surprising to the Palestinian Authority and its negotiators. President Mahmoud Abbas stated that "the Palestinians waited for President Trump to disclose the deal of the century, but in a fair manner to their rights, and if it is directed to them the slap of the century" (Al-Azar, 2018, p. 92). Lakhdar Brahimi, former Algerian foreign minister and a veteran of his country's liberation struggle, said, "This is a conflict rooted in injustice, dispossession and disdain for rights and law. Abandoning negotiations and imposing annexation will only entrench these problems" ("The Elders Warn New US", 2020). Trump's peace plan will lead to more Middle East conflict. 


\section{CONCLUSION}

Until further notice, the Trump administration aims to liquidate the Palestinian issue. Thus, adding fuel to fire, the Trump administration has intensified the feeling of resentment between Arabs and Jews. Through new policies towards a final solution, Americans withdrew from any commitment to the Palestinians in accordance with international legitimacy decisions and international agreements. They seek to impose a new American political settlement that simulates the Israeli vision and goals, and end Palestinian demands of an independent state on the borders of 1967 with its capital, occupied East Jerusalem, using economy and political money as an input to settle the conflict rather than a political solution.

Real progress is unlikely at the level of the peace process under the hard-right Israeli government officials who refused to make real concessions to achieve a just and comprehensive peace. A resolution to the Israeli-Palestinian conflict serves to improve security. Hostilities between Arabs and Israelis have long been a hot threat in the Middle East, provoking several crises and wars over the past 50 years. Moreover, Washington's support for Israel and perceived hostilities toward Arabs and Muslims has fuelled anti-US and Anti-Israeli sentiments in the region.

There is a marginal continuity in Trump's policy toward Israeli-Palestinian issues, with the United States always defining the goal of resolving the issue between Israel and the Palestinians. However, Trump has proved that he has added several changes that "exonerate" his predecessors by moving the U.S. embassy and cutting Palestinian aid. These policies have clearly provoked outrage throughout the Muslim world. Solutions to these issues have unequivocally demonstrated their one-sided approach, especially when Trump sent the head of a pro-Israel peacekeeping team, Jared Kushner, a Jewish man, and David Friedman and Jason Greenblatt who have personal affairs with the Israeli government.

Recognising Jerusalem as Israel's capital without limiting the land area and halting funding for Palestine is not just a policy of uncertainty, but it adds more pain to Palestinian society. Moreover, Trump's rhetoric and policy have caused major changes that are impossible to return to, but this conflict could be modified in the future, by handing these negotiations over to organisations to be far more transparent intermediaries than the U.S. government.

Essentially the Palestinians have been told to take it or leave it. They are being given a surrender document, told to accept that Israel has won, and with its American friends will shape the future. If Palestinians refuse, the message continues, Israel will still get what it wants and they will be even worse off. The Trump plan is a gamble. The absence of hope has placed both sides on the defensive side. Only radicals' ideas gain power as the divergence deepens. Ending the deadlock and restoring a sense of possibility remains essential to preserving a realistic endgame of two states for two people. There is a chance Palestinians will be afflicted by more anger, despair and hopelessness. 


\section{BIBLIOGRAPHY}

Adam, Karna. et al. (2015, November 4). "Time for a Change: The Role of the United States in the Israeli-Palestinian Conflict". Rockefeller Center for Public Policy, Task Force Report, Fall 2015.

Ahmed S. A. (2017, January 22). "Trump and Middle East Issues: Limits of Change," International Policy. Retrieved from http://www.siyassa.org.eg

Al Jazeera, (2016, March 2). "What Would Donald Trump Mean For The Middle East? Could The Republican Candidate's Proclaimed 'Neutrality' On Israel-Palestine Offset His Rhetoric About Muslims?" Retrieved from http:/www.aljazeera.com/indepth/ features/2016/03/donald-trump-middle-east 160302065322917.html

Al-Azar, Muhammad Khaled (2018, March12). "The Implications of Recent Israeli Decisions on Jerusalem and Its Implications", Arab Affairs Magazine, p. 86-98, p. 92.

Al-Jazeera, (2017, November 14). "Times: Ibn Salman presses Abbas to accept the Trump initiative." Retrieved from https://tinyurl.com/y3gp4csh

Al-Sahli, Nabil Mahmoud (2017, Spring). "U.S. Administrations and the Palestinian Cause". The Journal of Palestinian Affairs, pp. 58-73, p. 58.

Amin, Samir et al. (2004). Globalization and the New International System. Center for Arab Unity Studies, Lebanon: Arab Future Books Series, Beirut.

Anderson, S. R. (2017, December 11). "Trump's Jerusalem Policy is More Ambiguous than it seems." Foreign Policy. Retrieved from https://foreignpolicy.com/2017/12/11/trumpsjerusalem-policy-is-more-ambiguous-than-it-seems/

Basevich, Andrew (2004). The American Empire: The Facts and Consequences of American Diplomacy, (Lebanon: The Arab House for Science, Beirut, first edition, p. 37.

Boot, M. (2016, November 22). “Trump's 'America First' Is the Twilight of American Exceptionalism," Foreign Policy.

Bowen, Jeremy (2020, January 29). "Trump's Middle East peace plan: 'Deal of the Century' is Huge Gamble". BBC Middle East, Washington. Retrieved from https://www.bbc.com/news/world-middle-east-51263815.

Bremmer, Ian (2020, January 28). "How the Trump Administration's Israel-Palestine Peace Plan Will Change the Middle East." Time. Retrieved from https://time.com/5773138/trump-israel-palestine-peace-plan/

Curran, J. (2018). "Americanism, not globalism": President Trump and the American mission. Sydney: Lowy Institute.

Elgindy, K. (2019). Blind Spot: America and the Palestinians, from Balfour to Trump. Washington D.C: Brookings Institution Press.

Gearan, Anne (2005, February 4). "Rice Blasts Way Iran Treats Its Own People," Associated Press.

Greenberg, Joel. (2015, September 3). "Netanyahu to Continue Campaign Against Iran Nuclear Deal," The Wall Street Journal.

Gunnar, Ulson. (2017, April 02). "US Foreign Policy: Hegemony or Stability, Not Both". Global Research. http://www.globalresearch.ca/us-foreign-policy-hegemony-orstability-not-both $/ 5582758$.

Hadley, Stephen. (2008, January 10). White House press briefing. Retrieved from http://georgewbushwhitehouse.archives.gov/news/releases/2008/01/200801107.html.

Jaraba, Mahmoud \& Bin Sheetrit, Lehi (2016, December) . "The Palestinian-Israeli Conflict in Trump's Perspective," Al-Jazeera Center for Studies. Retrieved from http://studies.aljazeera.net/ar/reports/2016/12/161201103017333.html 
Jaraba, Mahmoud (2016, November 9). "The Implications of a Trump Presidency for the Middle East: Crushing Hopes of a Two-State Solution". Sada Journal, CEIP. Retrieved from https://Carnegieendowment.Org/Sada/65054

Keohane, R. (2005). After Hegemony: Cooperation and Discord in the World Political Economy, Princeton: Princeton University Press.

Khalidi, R. (2009). Sowing Crisis: The Cold War and American Dominance in the Middle East, Boston: Beacon.

Lee, Matthew (2010, January 7). "US Readies New Mideast Peace Push," Associated Press. Leverett, F. and Mann Leverett, H. (2012, November). "The Balance of Power, Public Goods, and the Lost Art of Grand Strategy: American Policy toward the Persian Gulf and Rising Asia in the 21st Century", Penn State Journal of Law and International Affairs, 1/2, 21618.

Leverett, F. and Mann Leverett, H. (2013). "Going to Tehran: Why America Must Accept the Islamic Republic of Iran”, New York: Metropolitan/Picador.

Lustick, Ian (2017, February 22). "Could Trump's Radical Approach Bring Peace to Israel and Palestine." The Guardian. Retrieved from https://www.theguardian.com/commentisfree/2017/feb/22/trump-peace-israelpalestine-two-state-solution.

Mearsheimer, J. (2011, January/ February). "Imperial by Design". National Interest. http://nationalinterest.org/article/imperial-bydesign-4576 .

Migdalovitz, Carol (2006, March 16). "The Middle East Peace Talks". CRS Issue Brief for Congress.

Migdalovitz, Carol (2010). Israeli-Arab Negotiations: Background, Conflicts, and U. S. Policy. DIANE Publishing.

Migdalovitz, Carol, (2010, January 29). "Israeli-Arab Negotiations: Background, Conflicts, and U. S Policy", Washington: Congressional Research Service.

Muhammad Hussein, Muhammad (2017, July 18). "American Policy in the Obama Era and its Implications for the American Role in Solving the Palestinian-Israeli Conflict." The Arab Democratic Center. Retrieved from http://www.democraticac.de/?p=47804

Nasr, Vali. (2016, November 25). "Trump's Big Test in the Middle East," The Atlantic.

Pagliarulo, Diego (2017, January 3). "Donald Trump, the Middle East, and American Foreign Policy". E-International Relations. Retrieved from https://www.eir.info/2017/01/03/donald-trump-the-middle-east-and-american-foreign-policy/

Perry, William J. (1995, April). "Gulf Security and U. S Policy". Middle East Policy.

Pijovic, Nikola (2016, November). "How Trump Will Test International Relations Theory: Will The Realists Or The Constructivists Be Proved Right?" International Relations, Asia, the World. Retrieved from https://www.policyforum.net/trumpwill-test-internationalrelations-theoryl

President Receives A Call From Hamas Leader, Haniyeh". Wafa News Agency, 28 January 2020. Retrieved from http://english.wafa.ps/Pages/Details/101139

Quandt, Willian, (1981). Sudian Arabian Foreign Policy in 1985, Security and Oil. Washington DC: Brooking Institution.

Rinehart, C. S. (2018, Spring). "President Trump and Jerusalem: The Effects of the Relocation of the American Embassy on the Israeli-Palestinian Peace Process". The Journal for Interdisciplinary Middle Eastern Studies Vol. 2.

Siegman, Henry (2017, April). "U.S. Middle East Policy and the Peace Process". U.S./Middle East Project. Retrieved from https://www.cfr.org/content/publications/attachments/ Middle_East_Policy.pdf 
Suleiman, Yemeni (2016, May 21) . "Donald Trump's U.S. Foreign Policy Directions." The Egyptian Institute for Political and Strategic Studies. Retrieved from https://tinyurl.com/y2pcsl27

"The American Position on the Palestinian Question". Aljazeera.net, 7 February 2012. Retrieved from http://www.aljazeera.net/knowledgegate/opinions/2012/2/7/

"The Bahrain Conference Concludes its Work and Kushner Confirms that the Door is Open to the Palestinians." France 24, 26 June 2019. Retrieved from https://tinyurl.com/yyaalrpr

“The Elders Warn New US 'Peace' Plan for Middle East is Unworkable”. The Elders, 29 January 2020. Retrieved from https://www.theelders.org/news/elders-warn-new-uspeace-plan-middle-east-unworkable

"The Expected Policy of the Trump Administration toward the Palestinian-Israeli Conflict." Arab Center for Research and Policy Studies, Qatar, (29 January 2017). Retrieved from https://www.alaraby.co.uk/opinion/2017/1/29/

Tllovska-Kechedji, E. (2018). "Israeli-Palestinian Relations: Waging for Peace or Lost Desperately". International E-Journal of Advances in Social Sciences, 4/10, 120-130.

“Trump Says His Mideast Peace Plan Provides A 'Realistic Two-State Solution'". NPR, 28 January 2020. Retrieved from https:/www.npr.org/2020/01/28/800296507/whitehouse-to-unveil-mideast-peace-plan-despite-palestinian-rejection

Trump, D. (2016, April 27). "Donald J. Trump Foreign Policy Speech".

"Trump's executive order: Who does travel ban affect?" The BBC, 27 January 2017. http:// www.bbc.com/news/ world-us-canada-38781302

U.S. Senate, (2003, October 15). "The Middle East Road Map: Overcoming Obstacles to Peace".

Vatikiotis, PJ, Op. (1971). Conflict in the Middle East. Ruskin House.

Walt, Stephen \& Mearsheimer, John. (2007). The Israel Lobby and American Foreign Policy. New York: Farrar, Straus and Giroux.

Wermenbol, G. (2019). Israel-Palestine and the Deal of the Century. U.S. Foreign Policy under President Donald J. Trump 2017-2019. Washington D.C: Friedrich-Ebert-Stiftung.

"What after Trump Declared Jerusalem the Capital of Israel?" Strategic Fiker Center for Studies, 2017-12-22. https://fikercenter.com//assets/uploads/qudos.pdf

Ziada, Ekram. (2017). "The Future Position of the United States of America Toward the Palestinian Issue Under President Trump's Rule," in: The Middle East Under American Foreign Policy Agendas, An Analytical Study of the Transition Between Obama and Trump Rule, vol. 1, Berlin / Germany, Arab Democratic Centre for Strategic Studies Political, Economic.

Ziadeh, Ikram (2017). "The Future Position of the United States on the Palestinian Issue under President Trump”. In: Hadi al-Shayeb and Samira Nasseri, Middle East under U.S. Foreign Policy Agendas (An Analysis Of The Transition Period Between Obama and Trump), Berlin, Arab Democratic Center for Strategic, Political and Economic Studies. 


\section{ENDNOTES}

1 The U.S. economy is heavily dependent on imported oil; with the U.S. machine consuming $30 \%$ of the world's oil even though its population is only $6 \%$. The U.S., with $4.5 \%$ of the world's population, consumes $24 \%$ of the world's oil production per year; $66 \%$ of that oil is imported. World Energy Use, Physics - Lumen Learning. https://courses.lumenlearning.com/physics/chapter/7-9-worldenergy-use.

2 See Keohane, R. After Hegemony: Cooperation and Discord in the World Political Economy, Princeton: Princeton University Press, 2005, pp. 139-41, 150-81, 190-95, 202-06; Khalidi, R. Sowing Crisis: The Cold War and American Dominance in the Middle East, Boston: Beacon, 2009, pp. 6-16, 40-62, 107-11; and Leverett, F. and Mann Leverett, H. "The Balance of Power, Public Goods, and the Lost Art of Grand Strategy: American Policy toward the Persian Gulf and Rising Asia in the 21st Century", Penn State Journal of Law and International Affairs, 1:2, pp. 216-18, November 2012.

3 The U.S. became a net oil importer by the early 1970s; since then it has never met a high percentage of its oil demand with Middle East imports. See Leverett and Mann Leverett, 'The Balance of Power, Public Goods, and the Lost Art of Grand Strategy', 2012, pp. 210-11.

4 For critical assessments, see Mearsheimer, J. 'Imperial by Design', National Interest, January/ February 2011, http://nationalinterest.org/article/imperial-bydesign-4576 (accessed 22 Dec. 2016); and Leverett, F. and Mann Leverett, H. Going to Tehran: Why America Must Accept the Islamic Republic of Iran, New York: Metropolitan/Picador, 2013, pp. 1-11, 328-34.

5 Greenblatt, Jason U.S. President Donald Trump's resigned special envoy to the Middle East and a key figure in the administration's work on an Israeli-Palestinian peace plan.

6 The plan calls for projects worth \$27.5bn in the West Bank and Gaza, and \$9.1bn, \$7.4bn and \$6.3bn for Palestinians in Egypt, Jordan and Lebanon respectively. The projects envisioned are in the healthcare, education, power, water, high-tech, tourism and agriculture sectors. 